\title{
Accessibility in disaster-resilient cities
}

\author{
Hatice Ayataç* (D)
}

\begin{abstract}
According to the World Health Organization, disasters are the unexpected consequences of occurrences that cause a level of suffering that exceeds the capacity of adjustment of the affected community. Available records indicate that natural, technological and man-made disasters -by causing loss of lives and property- affected more than 4 billion people worldwide in the last 20 years. People with disabilities are among those who are highly fragile and physically vulnerable to the dangers and risks posed by disasters. The actual reason behind why people with disabilities are rather vulnerable to the adverse effects of natural and man-made disasters is the fact that they have no access to social, spatial and civil resources. According to the United Nations Inclusive Disaster Risk Management Report, in the event of disasters and emergencies, individuals with disabilities are affected disproportionately due to the inaccessibility of the evacuation, response, and rescue efforts. The 7th Millennium Development Goal (1990-2015) emphasizes that improvements in humans' lives and in the environment are critical to ensure environmental sustainability, and it highlights the need to 'build a disaster-resilient community.' Resilience to urban disasters shows a community's ability to adapt to natural and man-made disasters and hazards, to keep any potential threats away, and to evaluate the consequences and modify existing conditions. This study focuses on accessibility in disaster-resilient cities, and it aims to evaluate the components of urban resilience, which helps to eliminate the damages of disasters and to recover, with a particular focus on the accessibility of individuals with disabilities. Based on the available literature, the study evaluates the outcomes of a workshop that was conducted with 40 participants in AugustSeptember 2021 as one of the events in preparation for MARUF21. The participants were local officials who are in charge of and accountable for disaster and emergency management, and individuals who are vulnerable to disasters and emergencies. The findings and results of the study are presented under four headings: (i) Accessibility of Urban Spaces in Disaster and Emergency Management, (ii) Risk Management and Accessibility in Cultural Heritage Areas, (iii) Social Policies and Accessibility in Disaster and Emergency Management, and (iv) Accessibility to Communication, Technology and Innovations. The study highlights that accessibility in disaster and emergency management extends beyond spatial organization, and it is a prerequisite for social harmony and disaster resilience.
\end{abstract}

Keywords: disaster mitigation, disability, resilient cities, accessibility, risk management 


\section{Introduction}

Each year, disasters affect millions of people worldwide and cause loss of life and property. According to the United Nations (UN, 2018), "a disaster is a serious disruption to the functioning of a community, which causes human, material, economic and environmental losses beyond a community's ability to cope." In simple words, a disaster is the consequences of an event and not the event itself (AFAD, 2014).

Natural disasters include earthquakes, floods, landslides, droughts, and storms, while technological disasters include dam failures, agricultural accidents, economic depressions, and collapse of the electronic infrastructure, and fires, water and environmental pollution, and transport accidents are classified as man-made disasters (Kadığlu, 2008). Disasters can also be defined as "the unexpected consequences of occurrences that cause a level of suffering that exceeds the capacity of adjustment of the affected community" (WHO, 2013).

People with disabilities are among those who are highly fragile and physically vulnerable to the dangers and risks posed by disasters (AFAD, 2014). According to the World Health Organization (WHO, 2013), people with disabilities are individuals who have impairments of their body structure or body functions, have limited mobility, and face difficulty in performing a task or an action, and they correspond to $15 \%$ of the world's population. ${ }^{1}$ When evaluated with a perspective on emergency and disaster management, people with disabilities can be classified as individuals with special needs, and they can be defined as "individuals who require additional or specialized services or adjustments in order to be adequately prepared for disasters and emergencies, to take the necessary actions in the event of such events, and to fulfill their needs in the aftermath of a disaster or emergency" (Subaş Yurtçu, 2019).

According to the UN Convention on the Rights of Persons with Disabilities (Article 9 of the CRPD, 2008), individuals with disabilities can live independently and participate actively in all aspects of life only if they are provided with equal access to the physical environment, to transportation, to information and communication technologies, and to the facilities and services available in both urban and rural areas. The actual reason behind why people with disabilities are rather vulnerable to the adverse effects of natural and man-made disasters is the fact that they have no access to social, spatial and civil resources. According to the UN Inclusive Disaster Risk Management Report (2018), in the event of disasters and emergencies, individuals with disabilities are affected disproportionately due to the inaccessibility of the evacuation, response (shelters, camps, and food distribution), and rescue efforts. Environmental hazards and natural disasters lead to the emergence of different types of disabilities, and inaccessible environments prevent people with disabilities from participating in economic and social activities. The 7th Millennium Development Goal (2015) emphasizes that improvements in humans' lives and in the environment are critical to ensure environmental sustainability.

Ensuring that people with disabilities have access to all amenities and services will help them to endure the hazards they face during disasters and will help to increase their resilience. Nowadays, 'building a disaster resilient community' is a common vision both in the international and in the domestic agenda (Jha et al., 2013; AFAD, 2011).

Resilience, which was coined by Holling (1973), was first discussed within the realms of ecology, and it was defined as the capacity of a system to recover from and adapt to any disruptions and damages. Over time, the concept also gained ground in other disciplines including social sciences, urbanism and urban design. In urbanism and urban design, resilience refers to understanding the

\footnotetext{
${ }^{1} 3.2 \%$ of the world's population (approximately 253 million people) suffers from blindness or visual impairments, while 466 million people worldwide ( $6 \%$ of the world's population) suffer from deafness and hearing loss. Roughly 200 million people have an intellectual disability, and 75 million individuals need to use a wheelchair (https://www.inclusivecitymaker.com/disabled-people-in-the-world-in2021-facts-and-figures/). (Url-1)
} 
dynamics in a city or part of a city in order to ensure increased ability to endure and adapt to any potential changes or threats. Urban resilience has become a popular concept on account of the fact that it enables improving the living conditions, increasing the level of knowledge, and creating a multi-actor process in decision making.

Resilience to urban disasters indicates a community's ability to adapt to natural and man-made disasters and hazards, to keep any potential threats away, and to evaluate the consequences and modify existing conditions (UNISDR, 2011). When it comes to urban resilience to disasters, it is necessary to focus on solutions in the long run. Therefore, resilience to urban disasters should be addressed in infrastructural, institutional, economic and social dimensions (Jha et al., 2013), (Figure. 1).

\section{Components of Urban Disaster Resilience}

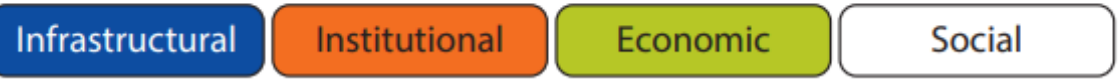

Figure 1 Components of Urban Disaster Resilience (Jha et al. 2013)

The resilience of the urban infrastructure (water, sanitation, energy, communication, and transportation) refers to eliminating the vulnerabilities of the built environment including buildings and transportation systems. It also indicates the housing capacity in cities, healthcare facilities, vulnerabilities of buildings to disasters, and the availability of evacuation routes and supply lines after disasters. The resilience of the infrastructure is directly related to the recovery capacity of a community. Institutional resilience refers to the capacity of those who are in charge of managing communities, such as governments and non-governmental bodies. Economic resilience illustrates the employment diversity in communities, and it refers to the capability to do work in the aftermath of a disaster. Social resilience indicates the demographic profile of communities, and it refers to the aspects of the social capital including age, gender, disability, ethnic background, immigrants, etc. The tie between social capital and place, and the sense of belonging are deciding factors during recovery from any vulnerability that affects the entire community (Cutter, Burton and Emrich, 2010 in Jha et al., 2013).

This study focuses on accessibility in disaster-resilient cities, and it aims to evaluate the components of urban resilience, which helps to eliminate the damages of disasters and to recover, with a particular focus on the accessibility of individuals with disabilities. Based on the available literature, the study evaluates the outcomes of the workshop that was conducted with local officials who are in charge of and accountable for disaster and emergency management, and participants who are vulnerable to disasters and emergencies.

\section{Disaster Risk Management and Opportunities for Resilience}

Referring to the statistics indicating that $60 \%$ of the world's population will live in cities by 2050 , many experts suggest that a great number of mega cities are at peril of natural disasters including earthquakes, tsunamis, landslides, floods, and droughts. Risks are intensified not only due to the predisposition to disasters and risk levels in cities, but also due to increased migration, unplanned urbanization, insufficiency of resources, lack of knowledge, experience and equipment as well as unpreparedness (Urbanization Council, 2009). In order to alleviate risks and the vulnerability of communities and to eliminate the adverse consequences of disasters, it is necessary to formulate strategies to tackle disasters, and to carry out the necessary legal, political and technical studies (Urbanization Council, 2009). These can be collectively identified as 'disaster risk reduction' activities (Erdin, 2018). 
Disaster risk management entails making the necessary administrative decisions, operational abilities, technical studies, intervention capacities, and preparations viable by means of legislative regulations as well as identifying and continuously practicing the necessary strategies and methods (Ertugay ve Düzgün, 2006). In other words, risk management is the process where hazards and risks are identified and analyzed, opportunities, resources and priorities to prevent and/or eliminate risks are identified, and policies, strategies and action plans are developed and put in practice (AFAD, 2014; Kadıoğlu, 2008). Today, disaster risk management refers to the analysis, planning, decision making and assessment processes that altogether organizes available resources for the purposes of (i) being prepared for any hazards, (ii) eliminating damage and risk, (iii) intervention, and (iv) recovery (AFAD, 2014; Kadıoğlu, 2008).

In 1987, the declaration of 1990-2000 as the International Decade for Natural Disaster Reduction (IDNDR) by the UN General Assembly (UN Resolution 42/169, 1987) paved the way for other important steps worldwide towards reducing disaster risk. Other critical steps to reduce the risks related to natural disasters include the Yokohama Strategy and Plan of Action for a Safer World (1994), the UN Millennium Declaration (2000), the International Strategy for Disaster Reduction (ISDR) (2000), the 'Global Assessment Report on Disaster Risk Reduction' (2004) prepared by the United Nations Development Programme (UNDP), the World Conference on Disaster Reduction and the Hyogo Declaration (2005) and the Hyogo Framework for Action (2005-2015) the Global Platform for Disaster Risk Reduction (2007). (AFAD, 2015),

In addition, the UN Conference on Environment and Development (the Rio Summit) concluded that sustainable economic development and sustainable development goals cannot be achieved unless adequate precautions and measures are taken to reduce disaster-related losses and highlighted the tight relationship between losses related to disasters and environmental degradation. The UN Conference on Sustainable Development organized in 2002 and 2012 (Rio+10 and Rio+20) accepted that settlements are highly vulnerable to disasters, and emphasized that, in order to reduce disaster-related damages, it is critical to take precautions aimed at reducing risks prior to disasters (Jha et al, 2013). The UN's Incheon Conference (South Korea, 2009) and the Incheon Declaration identified local governments as global actors (independent from central governments) given that risk reduction practices are usually performed at the local level, and also indicated that expenditures for risk reduction should be identified as 'investments' rather than 'costs.' Moreover, as an outcome of the Incheon resolutions, the 'Resilient Cities' campaign was launched (2010-2011). The International Strategy for Disaster Reduction not only identified the topics that local governments should consider in their risk reduction efforts, but also endeavored to include local governments in the process, to ensure experience sharing between local governments, to promote best practices, and to build a network of local governments. In late 1970s, the concept of resilience was solely used to understand the changes and the balance in ecology; however, by mid-1990s, the concept made its way in studies on disaster risk reduction. According to the UN ISDR (2009), urban resilience is "the ability of a system, community or society exposed to hazards to resist, absorb, accommodate to and recover from the effects of a hazard in a timely and efficient manner, including through the preservation and restoration of its essential basic structures and functions." In this definition, it is apparent that urban resilience does not only refer to structural durability and the ability to avoid damages, but it also refers to ensuring sustainability in settlements and to taking the necessary precautions to adapt to global events such as the climate change. According to the 'Making Cities Safe' campaign launched by the UNISDR, in resilient cities:

- Residents join local decision-makers as they plan and make decisions about the city based on the capacity and available resources,

- Local governments are competent and accountable ensuring the participation of all groups in the city to achieve sustainable urbanization,

- The entire population lives in housing and neighborhoods with adequate infrastructure and services, 
- Many disasters are prevented by ensuring no informal settlements are built in flood plains or steep slopes, and by making sure that the city is built rationally built pursuant to development regulations,

- There is a robust local information infrastructure that detects hazards and considers the hazards and risks in relation to those who are affected and who are vulnerable,

- Necessary steps are taken to foresee disasters and to protect its assets,

- The amount of physical and social losses related to extreme weather conditions, earthquakes and other hazards are minimized, and

- The provision of the necessary resources prior to, during or after a disaster is guaranteed, and there is the ability to recover.

Currently, the Millennium Development Goals (UNDP, 2010) and the Hyogo Framework for Action (2005) are in effect to address the relation between disasters and development at the global scale.

The strategic goals of the Hyogo Framework for Action are: (1) integrating the risk reduction strategies to sustainable development policies and plans, (2) building and reinforcing the necessary organizations, mechanisms and capacity to increase awareness on disasters, and (3) systematically integrating the risk reduction approaches to emergency preparation, intervention and recovery programs. The actions with priority in the Hyogo Framework for Action are: (1) Organizational management: Reducing disaster risk and ensuring that strong organizational structures exist for implementation at the national and regional levels, (2) Definition of risk: Defining, assessing, monitoring disaster risks and developing early warning systems, 3) Information and education: Utilizing information, innovation and education to build a safe community highly aware of disasters, 4) Risk reduction: Reducing the risk factors that lie behind disaster risks, and 5) Readiness: Improving readiness at all levels for any type of disaster (Orhan \& Keskinok, 2019; Orhan, 2010).

Local and central governments are primarily responsible of disaster risk management; therefore, they identify various enforcements to protect communities from the adverse consequences of disasters and to achieve resilience (UNISDR, 2011). In urban space, this entails ensuring safe and affordable urban infrastructure, identifying the building arrangement principles and overseeing the relevant expenditures, defining a disaster-safe layout for the settlement, and informing and guiding the local community. It is critical to ensure that the legal and administrative framework that is developed by local governments is put in practice and embraced by civil society, the private sector as well as national and regional organizations (Balamir, 2001).

Disaster risk management also proves to be a great opportunity to improve urban resilience. Disaster risk management should be performed with the participation of various stakeholders and sectors. According to the Hyogo Framework of Action comprehensive disaster risk management entails (a) identifying, assessing, and monitoring risk; (b) reducing risk through prevention and mitigation measures; (c) disaster risk financing and insurance; (d) emergency preparedness; and (e) post-disaster response, recovery, and reconstruction that reduces risk from future events (Jha et al., 2013)

When evaluated with an urban planning perspective, decision makers are in charge of achieving adequate level of preparedness before disasters, undertaking the expenses attached to intervention, rescue and recovery efforts. Making an accurate analysis of disasters eliminates the reasons in the disaster cycle and provides opportunities for disaster resilience. The 6 phases of the disaster cycle are presented in Figure 2. 


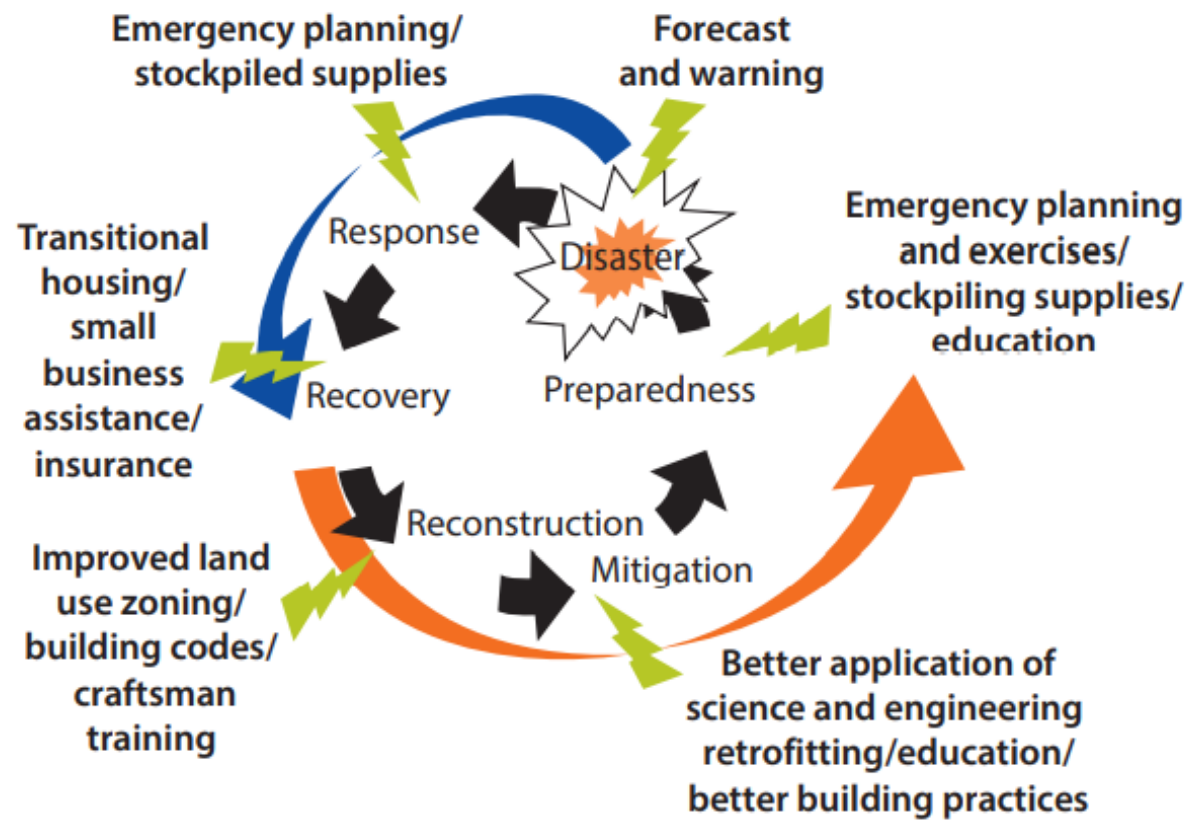

Page | 300

Figure 2 The six phases of the Disaster Cycle, Jha et al., 2013

The 'mitigation phase' involves not only enhancing resilience by reinforcing community ties, social organizations, and the economic base but also taking lessons from previous disasters to ensure sustainable urban development both for the present time and for the future. In the 'preparedness phase,' it is necessary to get prepared for the next disaster by means of preparing disaster and evacuation plans, performing trainings, and ensuring supplies are adequately stocked. In the 'disaster phase,' the focus is on warning and evacuation to reduce losses and to respond swiftly. In this respect, warnings allow for finding a shelter and moving valuable goods, foodstuffs, animals and vehicles. The 'response phase' involves rescue operations, public health precautions, shelter arrangements and food distribution. Interventions, such as containing fires and release of hazardous materials, emergency repairs to prevent further infrastructure failures, and restoration of crucial services, are aimed at preventing any major damage. The duration of this phase depends on the scale and type of the disaster and the amount of areas affected from the disaster. During the 'recovery phase,' which may take months depending on the size and the scale of the disaster, the aim is to recover social and economic functions, to move communities into semi-permanent housing, to reopen schools, to restore community organization, and to rebuild the infrastructure necessary for the economy to begin to function. The 'reconstruction phase' may take months to years given that it involves restoring what was lost as much as possible. Early in this phase, emergency responders leave the stage to normal government agencies (Kadıoğlu, 2008; Urbanization Council, 2009: Subaş Yurtçu, 2019).

\section{Accessibility in Disaster and Emergency Management}

According to the emergency events database (EM-DAT) of the Centre for Research on the Epidemiology of Disasters (CRED), which has the most comprehensive database on disasters worldwide, 7348 natural disasters were reported in the last two decades (2000-2019). Over the period of time between 2000 and 2019, 3254 (44\%) floods, 2043 (28\%) hurricanes, 552 (8\%) earthquakes, $432(6 \%)$ extreme heat events, 376 (5\%) landslides, and $338(5 \%)$ droughts were reported worldwide (Turkish Red Crescent World Disaster Report, 2020). As a consequence of these disasters, more than 4 billion people around the world lost their lives or properties. According to the General Directorate of Meteorology (MGM) and official figures, in 2020, the number of natural disasters in Turkey reached the peak number of 984 (Doğan, 2021). 
The research carried out by the Turkish Statistical Institute (TÜiK) and the Administration of Persons with Disabilities (ÖZIDA) indicate that there are 8.5 million people with disabilities in Turkey, and the number of people affected by disabilities reach 30 million when family members are included (AFAD, 2011). In the Bulletin on the Statistics on Persons with Disabilities and Elderly (2019), which was published by the General Directorate of Services for Persons with Disabilities and Elderly at the Ministry of Family and Social Services, in Turkey, $6.9 \%$ of the individuals aged 3 or older have one or more disabilities. Although the exact number of persons with disabilities affected from disasters remains unknown, the figures above enable us to calculate the possibilities and estimate the risks (AFAD, 2020).

Pursuant to the current international and domestic regulations and guidelines, in the event of a disaster and emergency, particularly individuals with disability should have access both to social resources and to communication so that they can receive information and support (UNISDR, 2014). Audio methods should be used to access persons with visual disabilities, while methods that stimulate other senses should be utilized to access those with hearing loss. Some auxiliary systems are quite useful during emergency events. Social accessibility is achieved by information and communications systems. For each and every individual, accessibility corresponds both to a product and to a service (Stough \& McAdams Ducy, 2014). Accessibility may be a right entitled by laws; however, it should be provided in all spatial designs (Erdem et al, 2017).

\subsection{Research Methodology / The Workshop Module}

For the reasons and priorities mentioned above, an online workshop ${ }^{2}$ on accessibility in disaster and emergency management was organized in August-September 2021. The workshop aimed to discuss social resilience and early intervention with relevant stakeholders and develop proposals for solution with a particular focus on the spatial issues in settlements that occur due to natural disasters caused by climate change, and the vulnerable groups during disasters and emergency events. The workshop method ${ }^{3}$ was preferred because it is a hands-on scientific method that enables participants to work on and think and learn about a specific topic. Representatives from the Disaster and Emergency Management Presidency (AFAD), which is the primary organization in charge of disaster management in Turkey, representatives from the Turkish Red Crescent, representatives from local governments, representatives from a planning office plan involved in the implementation of plans, representatives from the General Directorate of Services for Persons with Disabilities and Elderly at the Ministry of Family and Social Services, academicians, Erişebilir Kent Atölyesi (EKA), and the Erişilebilir Her Şey Team participated the preparations of the workshop. Table 1 provides a summary of the roles and responsibilities of the participating stakeholders during an emergency event. The workshop was conducted in 4 phases: (1) informing organizations, discovering potentials, and getting familiar with the stakeholders, (2) brainstorming in sub-working groups with the guidance of moderators, (3) creating a common ground between groups, and (4) reporting.

Table 1 Participants of the workshop and their roles \& responsibilities in disaster management

\begin{tabular}{|l|l|l|}
\hline Organization & Responsibilities in Disasters and Emergencies & Workshop Participants \\
\hline AFAD & $\begin{array}{l}\text { Pre-disaster education, resource development, policy } \\
\text { and strategy formulation, staff training, cooperation, } \\
\text { coordination between stakeholders during disasters, } \\
\text { coordinating search and rescue efforts }\end{array}$ & $\begin{array}{l}\text { Office of the Governor of Eskişehir, } \\
\text { Provincial Directorate for Disaster and } \\
\text { Emergency Management }\end{array}$ \\
\hline Turkish Red Crescent & $\begin{array}{l}\text { Pre-disaster first aid trainings, raising awareness, } \\
\text { raising awareness among the vulnerable groups, }\end{array}$ & $\begin{array}{l}\text { Disaster Coordination Department of the } \\
\text { Turkish Red Crescent, }\end{array}$ \\
\hline
\end{tabular}

\footnotetext{
2 The Accessibility in Disaster and Emergency Management Workshop was carried out in the partnership of ITÜ and EKA-Erişilebilir Kent Atölyesi, and it was organized as part of the 'MARUF on the GO' activities that were carried out prior to the MARUF21.

${ }^{3}$ Workshop is a hands-on method preferred for activities where experts on a certain topic use cognitive processes for the transfer of knowledge. It is used to make preparations on a topic, and to develop ideas for the purposes of analysis and assessment. A workshop can be organized with as few as 5-10 participants or as many as 25-100 participants. The steps of a workshop are: (i) planning the preparations, (ii) working with the right stakeholders, providing the content, setting the rules, (iii) collecting individual ideas, (iv) brainstorming in sub-working groups, and (v) putting the finishing touches (Bo Westerlund, 2007).
} 


\begin{tabular}{|c|c|c|}
\hline & $\begin{array}{l}\text { protecting vulnerable groups, management of the } \\
\text { volunteering activities, emergency food services during } \\
\text { disasters, provision of emergency housing and other } \\
\text { services, management of the transition process with } \\
\text { mobile bakeries, mobile canteens and tents, } \\
\text { rehabilitation and training }\end{array}$ & $\begin{array}{l}\text { İstanbul Metropolitan Women's Branch } \\
\text { of the Turkish Red Crescent }\end{array}$ \\
\hline $\begin{array}{l}\text { Ministry of Family and Social } \\
\text { Services }\end{array}$ & $\begin{array}{l}\text { Developing, enforcing and auditing the legislation and } \\
\text { the standards on accessibility }\end{array}$ & $\begin{array}{l}\text { General Directorate of Services for } \\
\text { Persons with Disabilities and Elderly }\end{array}$ \\
\hline $\begin{array}{l}\text { Local governments and } \\
\text { planning \& design offices }\end{array}$ & $\begin{array}{l}\text { On-site surveying, field studies, redevelopment and } \\
\text { reinforcement activities }\end{array}$ & $\begin{array}{l}\text { ARI Urban Planning Office, Municipality of } \\
\text { Yalova, İzmir Metropolitan Municipality } \\
\text { (representing a local government that } \\
\text { was affected by a disaster) }\end{array}$ \\
\hline
\end{tabular}

During the introduction to the workshop, the definition of disaster and emergency was provided, and then, information on the participating stakeholders' roles, experiences and activities was provided. The Ministry helped to provide further explanation on the current legislation and practices. The workshop was conducted with 40 participants (Figure 3), and the sub-working groups were organized under four different themes: (1) Accessibility of Urban Spaces' in Disaster and Emergency Management (2) Risk Management and Accessibility in Cultural Heritage Areas (3) Social Policies and Accessibility in Disaster and Emergency Management (4) Accessibility to Communication, Technology and Innovations. The sub-working group for each theme was moderated by academicians who have extensive knowledge and experience on the theme in question. Equal representation between organizations was ensured in the sub-working groups of the main session. The discussions in each sub-working group was planned considering the three main phases of the disaster cycle (before, during and after the disaster).

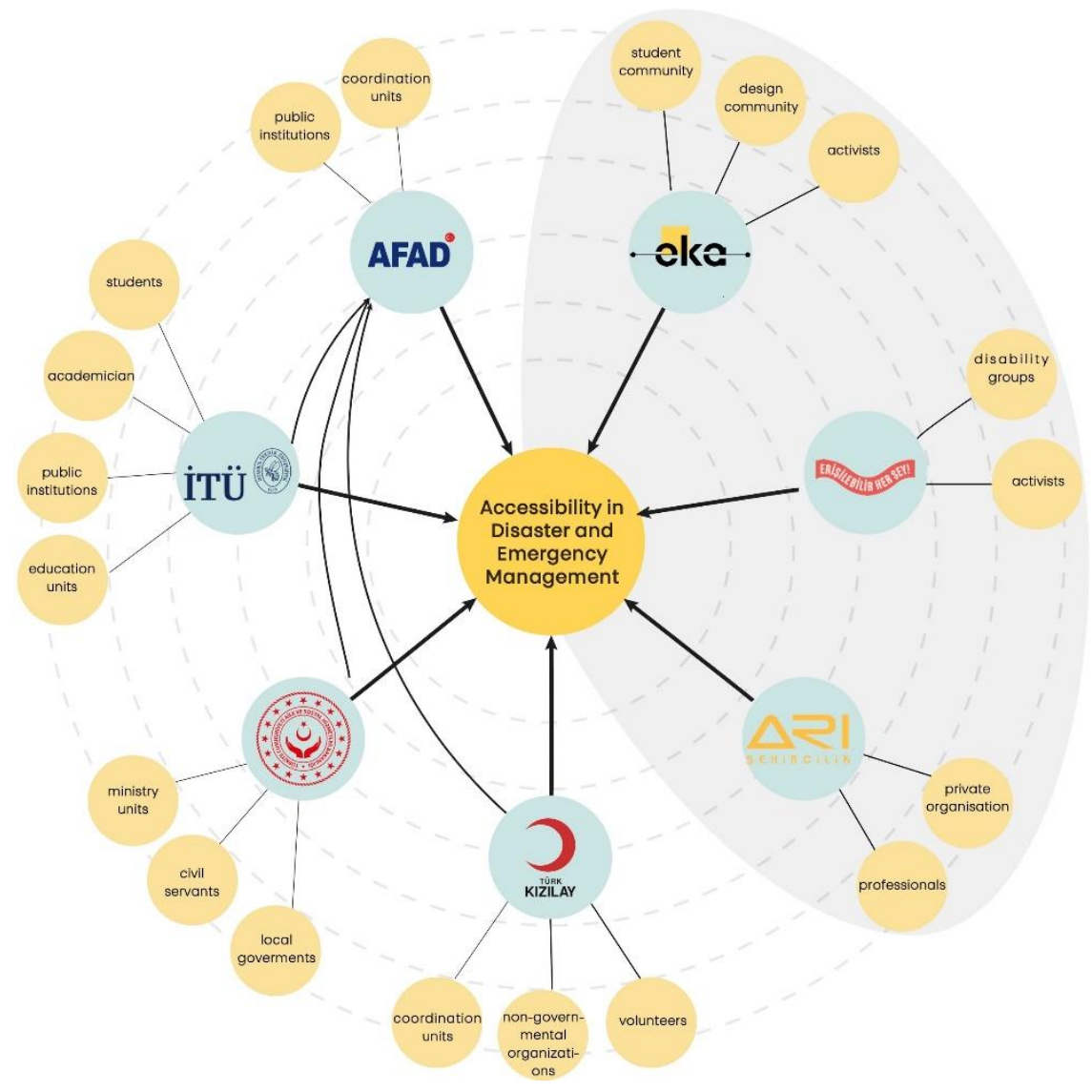

Figure 3 Workshop structure and participatory teams. 
For 45 minutes, two primary questions were asked to participants in each of the sub-working groups in the Miro interface:

Question 1. With respect to the theme of your sub-working group, which activities does the organization you represent carry out before, during and after a disaster?

Question 2. With respect to the activities that will be carried out during the disaster and emergency management processes in terms of your sub-working group's theme, what kind of recommendations and contributions would you make?

Moderators of each sub-working group presented an overall evaluation of the discussions in their groups by using the notes that were recorded with the Miro interface, and the common results were formulated. The workshop was conducted online, and it was completed within the designated timeframe of 3.5 hours.

In light of the outcomes of the workshop, the evaluations on and the recommendations for the current disaster and emergency management process in Turkey are provided under four headings.

\section{2. 'Accessibility of Urban Spaces' in Disaster and Emergency Management}

In cities, equal and quick access should be ensured when managing emergency before disasters, when ensuring coordination during disasters, and when shelters, food and logistics services are provided in the aftermath of a disaster. AFAD is in charge of coordinating this process. Each province in Turkey has a Provincial Level Disaster Risk Reduction Plan (IRAP).. ${ }^{4}$ Developed under the supervision of AFAD, these plans also enable communication between non-governmental organizations. In order to ensure that inspections, and disasters and emergencies are managed effectively, the efforts to manage relevant authorities under the same umbrella is aimed at achieving a coordinated and swiftly-operating system. In cities, AFAD and the Turkish Red Crescent carry out the training, awareness and education activities before disasters within an institutional framework. Especially non-governmental organizations (such as Erişebilir Her Şey) and teams that focus on accessibility (such as EKA, Point) strive to address the concept of accessibility in detail in the workshops they organize with the youth. The planning process in cities is managed by local governments along with urban planning offices, and projects on urban regeneration and smart cities are developed. The relevant ministries are in charge of inspecting fire escapes and monitoring other accessibility components in buildings and structures. It is possible to state that activities performed before disasters focus on reinforcing the existing structures, training and raising awareness, and making accurate analyses and assessments. During the planning process, the design of public spaces of priority during disasters and emergency events (such as children's playgrounds, sports fields, public parks, etc.), and site selection for housing should be strictly inspected by means of environmental impact assessment reports and, when necessary, plans should be utilized to eliminate any potential dangers in the physical space before disasters. "Vulnerability analyses," "disaster-resilient neighborhood analysis," "needs-impact analysis" (Kadıoğlu, 2008) and "evacuation plans" are the spatial studies that are highly recommended to be completed before any disasters occur.

To properly implement accessibility, cities should create an 'accessibility chain' 5 and strive to plan all urban activities around it. Pursuant to the 'accessibility' provisions in Article 9 of the United

\footnotetext{
${ }^{4}$ Provincial Level Disaster Risk Reduction Plan (IRAP) is a plan that reveals the disaster risk in a province as well as the potential effects of disasters, and it identifies the activities that should be performed and the people in charge of performing these before any disasters occur. The IRAP is formulated as a road map that should be developed with the collaboration of the institutions/organizations and all other relevant stakeholders in provinces. The IRAP should be adopted and put in practice by the entire province, and not by any particular institution or organization. IRAP is not a document that can be prepared and reported only once. Given that provinces have different dynamics and disaster risks, the local stakeholders in each province should identify the dangers, risks and risk reduction activities for their province and put the IRAP in practice as soon as possible. URL-2: https://irap.afad.gov.tr/en/42071/ABOUT-IRAP

${ }^{5}$ Accessibility chain indicates that the outdoor and indoor built environment as well as the transportation and information services that individuals use as they make their way from home to their destination and back to fulfill their social roles are fully accessible (Karadağ et al. 2020).
} 
Nations Convention on the Rights of Persons with Disabilities, "to enable persons with disabilities to live independently and participate fully in all aspects of life, States Parties shall take appropriate measures to ensure to persons with disabilities access, on an equal basis with others, to the physical environment, to transportation, to information and communications, including information and communications technologies and systems, and to other facilities and services open or provided to the public, both in urban and in rural areas" (2006/9). This provision defines "accessibility in buildings, and uninterrupted accessibility chain in the transportation system between places" as a condition to ensure that persons with disabilities can live independently and participate fully in social life (Hansen, 2009). In the research titled "Problems and Expectations of Persons with Disability," $66.3 \%$ of the persons with disabilities in Turkey state that the building they live in is not accessible, $58.4 \%$ indicate that public buildings are not accessible, and $66.9 \%$ express that pedestrian roads and pedestrian crossings are not appropriate for the use of persons with disabilities (TÜiK, 2010, pp.25-26). If the accessibility chain is not planned adequately in sidewalks and pedestrian crossings, buildings and yard gates, it is very likely that the accessibility chain will get interrupted in the event of a disaster or emergency. This is also addressed in the Circular on Accessibility Monitoring and Inspection Forms (Karadağ et al,2020). Thus, it would the best option to design building entrances without any difference in elevation and without stairs. If this cannot be achieved, ramps in front yards should be designed. In order to ensure that individuals with disabilities and the elderly can move comfortably on an equal basis with others, in the built environment, the physical space should be designed pursuant to the national accessibility legislation in the Zoning Regulation for Planned Areas (PAiY, 2017), the relevant standards, the international conventions, and the constitutional provisions (Karadağ, 2020). In addition to achieving a spatial planning that considers disasters, temporary shelters and assembly points should be designed to accommodate any unforeseeable risks (Erdin et al, 2016: Sarı et al. 2018).

Disaster response plans are critical because they identify which places are accessible for whom in the event of a disaster or emergency. The actions that inform disaster response plans are (a) identifying the primary evacuation routes, (b) identifying the secondary evacuation routes, (c) assessing the possibility to reach areas that are highly used at nights, and (d) identifying alternative evacuation routes (Kadıoğlu \& Özdamar, 2008). Disaster response plans are critical because they identify which places are accessible for whom in the event of a disaster or emergency. In these plans, the coordination units and service groups that will be on duty in the event of a disaster or emergency should be identified, and the details of the organizations, teams and staff that are in charge of the operational plans should be provided.

Within the new spatial organization formed in the aftermath of a disaster, access to these essential activities is critical. Therefore, for disaster response teams, not only accessibility to the disaster area itself but also accessibility to the facilities that are used after the disaster (areas of deployment, logistics hub and storage areas, field hospital and mobile soup kitchens, alternative patient care locations, tent city locations, temporary shelter areas, public buildings and sports facilities appropriate for temporary housing, storage and distribution areas for aid and tents, etc.) is quite critical to ensure that post-disaster activities and services can be performed smoothly.

For the people who witnessed the disaster and who were affected by the disaster, accessibility means reaching safe areas before anything else. In this respect, immediately after an earthquake when panic is at its peak and people run to open spaces (time of the incident or immediately after the incident), accessible and safe open spaces are needed. Guiding decisions are necessary not only to eliminate or recover the consequences of a disaster but also to ensure that the temporary disaster coordination units select a safe site. Assembly points are typically outdoor public green spaces in adequate size that are in a convenient location for the residents and are accessible quickly in an organized manner. These are areas where those affected will spend time to comprehend what happened, to get help, to communicate with their loved ones, and to fulfill their needs temporarily. During the recent floods in Kastamonu and Sinop and the wildfires in southern Turkey, such areas 
were also affected by the disaster. In terms of flood risk management, spatial planning measures prove to be a rational solution for areas prone to medium or low flooding risk, whereas in areas under high flooding risk, spatial and structural solutions should be considered together (ITU Report, 2021)

Given that the spatial planning period in the aftermath of a disaster is actually the period of time before a potential disaster strikes, spatial planning efforts should be completed swiftly and persons with disabilities should be included in the process.

\subsection{Risk Management and Accessibility in Cultural Heritage Areas}

Until the 1990s, 'risk' and 'risk management' were not at all mentioned in cultural heritage areas. UNESCO's 1954 'Hague Convention for the Protection of Cultural Property in the Event of Armed Conflict,' which was enacted in the aftermath of the World War II, was the first international convention on the protection of cultural heritage against threats (Onur, 2019). In 1994, the concept of risk was addressed comprehensively for the first time in the 'Operational Guidelines' that was adopted in the World Heritage Committee's meeting in Phuket (Dinçer, 2012). In 1996, a declaration titled 'Cultural Heritage and Risk Readiness' was published following the meeting in Quebec, Canada (ICOMOS, 1996). In 1997, upon the call from Japan, the Kobe/Tokyo conference was organized with the title 'Risk Preparedness for Cultural Heritage,' and a concluding declaration was prepared (IATF, 1997). In 1998, with reference to IATF's heading on education and guidance, ICCROM's 'Risk Preparedness: A Management Manual for World Cultural Heritage' was published (Stovel, 1992). Risk preparedness and risk management were addressed in the World Conference on Disaster Reduction that was held in Kobe in 2005 - ten years after the city was hit by a major earthquake. Since 2005, risk and risk management were also included in the decisions and practices of the World Heritage Committee, and UNESCO formulated its principal approach to world heritage sites in the 'Disaster Risk Management Manuals.'

In Turkey, the Ministry of Culture and Tourism directly refers to the issue in the guidelines and specifications for the preparation of conservation plans with the following provision: "Conservation plans shall address the aims, strategies and implementation principles on how registered buildings, and the activities and the building stock in heritage sites shall be made more resilient and safe against disasters including but not limited to earthquakes, floods, landslides, rockfalls, etc. and these shall be included in the plan implementation report and plan notes." Another legislation in effect is the Regulation on the Preparation of Spatial Plans, prepared by the Ministry of Environment and Urbanism. When it comes to plans at the national level, AFAD's 'National Strategy and Action Plan on Earthquakes (UDSEP) 2023' addresses earthquake preparedness for cultural assets, and the 'Disaster Intervention Plan for Turkey' (TAMP) clarifies the interventions that will be performed for cultural assets after disasters (Zıvrali \& Cabbar, 2015).

When accessible routes are designed in cultural heritage sites, not only wheelchair-users, persons with mobility difficulties, and persons with visual disabilities but also the elderly, children, persons who use strollers, and individuals with attention deficit should be considered. In accessible routes, accessibility may be enhanced by placing notifications in Braille for persons with visual disabilities and designing ropes and tactile surfaces along the route for persons with disabilities (Güler Akın \& Tutal, 2017; Tutal, 2020).

In scope of the 'Accessibility Monitoring and Inspection' study, the Ministry of Culture and Tourism performs on-site inspections and monitoring to ensure physical accessibility for persons with disabilities in registered buildings. By suggesting the organization of arts \& culture events in historical sites, the 'Erişebilir Her Şey' initiative aimed to ensure that persons with disabilities can experience these sites and to put the question out for relevant authorities on how emergency rescue and evacuation can be performed in these sites in case of a disaster or emergency. In light of the recent disasters that struck cultural and touristic sites, this project brought recommendations on how individuals with disabilities can be evacuated in the event of a disaster, how accessibility to 
assembly points and outdoor public spaces can be ensured, and how accessibility to historic buildings can be provided for persons with disabilities. Evaluation reports on out-of-spec physical access features built in historic buildings and in their vicinities (such as accessibility ramps, entrance gates, elevators, restrooms, seating areas, etc.) were submitted to relevant authorities.

One of the most recent activities of the Turkish Red Crescent is a project that is conducted in Manavgat, Antalya in collaboration with the Ministry of Family and Social Services. The project helped to identify how tourists can move around in the aftermath of a disaster. Various tools were developed to ensure effective communication with foreign tourists, immigrants and refugees during and after disasters, and psychosocial aid was provided.

During the rescue efforts after the 2020 earthquake in İmir, the Turkish Red Crescent realized the emergence of an important social need, and thus, put up a tent to collect the personal belongings found in the disaster area and to return these to their owners. Such an effort can also ensure the protection of historic assets in the buildings located in cultural heritage sites. There is no department that is in charge of the protection and evacuation of cultural heritage sites in the event of a disaster. In historic sites and buildings, there are teams with the necessary technical knowledge and equipment. These should be organized as a team within the Turkish Red Crescent, and those who hold the required accreditation should be employed. In addition, raising awareness among local residents on risk reduction and safety measures in historically significant areas before a disaster may help to improve the sense of belonging and the awareness on preservation.

Ensuring that public officers and staff who are in charge of disaster management are trained with a particular focus on the vulnerabilities of persons with disabilities, ensuring on-site participation of individuals with disabilities to disaster drills, providing audio definitions of the interior and exterior plans of buildings for persons with visual disabilities, and placing audio warning signs are critical.

\subsection{Social Policies and Accessibility in Disaster and Emergency Management}

Accessibility is an important aspect of human life, and it means safely reaching and using any of the services provided to society. In this respect, accessibility can be considered as a human right in the sense that it refers to, for individuals and for communities, having the ability to fulfill basic needs, having access to social and cultural amenities and opportunities, and being able to benefit from and contribute in the services provided (Çağlar, 2012 in Kalaycı, 2020).

UN Convention on the Rights of Persons with Disabilities is an international document prepared to ensure that persons with disabilities can live independently with dignity. The convention, which is based on the Universal Declaration of Human Rights, is the primary global document that entails protecting the rights of persons with disabilities and preventing any discrimination against individuals with disabilities. Turkey signed the convention on 27 May 2009. The 'European Social Charter,' which was opened for signature by the European Union in 1961 and became effective in 1965, was signed by Turkey in 1961. Article 14 of the Charter defines the "right to benefit from social welfare services," while Article 15 explains "the right of physically or mentally disabled persons to vocational training, rehabilitation and social resettlement." In Turkey, the first regulation was enacted in 2005, and the Law on the Human Rights and Equality Institution of Turkey enacted in 2016 proves to be an additional support and contribution towards solving the accessibility problems that persons with disabilities face and considering the needs of individuals with disabilities. In addition, the Law No. 5378 on Persons with Disabilities secures the social rights of individuals with disabilities to access social resources and services.

In recent years, in Turkey and around the world, the need for social aid has intensified, thus making its way into the agenda as a social policy tool to combat poverty. The Social Assistance Directorate General (SADG) has the most extensive organizational structure and numerous programs to provide social aid services in Turkey, and the SADG utilizes the online database system 
called Social Assistance Information System (SOYBIS) to track the social assistance infrastructure. The Turkish Red Crescent and the Ministry of Family and Social Services archives the profiles of those affected from disasters in the Social Assistance Information System (SOYBIS). SOYBIS provides detailed information including household income, place of residence of household members, and number of persons with disabilities in the household, and the information is updated periodically (URL 3).

In scope of the comprehensive disaster management, descriptive and comprehensible animations were prepared for school children with visual disabilities and/or hearing loss to educate them on what to do before, during and after a disaster. The Turkish Red Crescent's 'Organizing the Community Leaders Project' entails selecting persons with influence on community (such as teachers, muhtars, religious officials, etc.) and training them on disaster awareness to spread knowledge and raise awareness among communities. The Club with no Disabilities within the Turkish Red Crescent offers first-aid trainings to volunteers. In order to mitigate disaster risks, a project on "how a mother can rescue her child, what can be done within the first 72 hours" is currently underway. The Turkish Red Crescent's Disaster System Module is being designed. Social aid requests will be collected in this system, and information such as which requests were fulfilled and what specific items are needed in a certain region will be stored digitally in this module (URL 4). Thus, equal access for all will be ensured.

In the event of a disaster or an extraordinary event such as a pandemic, education activities may be interrupted locally, and temporary or permanent solutions may be formulated depending on the effects of the disaster. During such times, it may look like digitalization in education makes things easier, but it may also lead to inequalities in education.

\subsection{Accessibility to Communication, Technology and Innovations}

Turkey is vulnerable to numerous natural disasters due to its geographic location. In addition to these, many disasters occur as a result of wrong decision-making processes, leading to significant loss of lives and property every year. The current communication technologies that enable us to access knowledge and the internet from virtually anywhere may prove to be helpful to prevent the emotional and material loss (Hoşgörmez, 2015).

New generation (4G and 5G) communication technologies enable rapid transfer of audio, video and data. Even though partially, phones provide uninterrupted communication in emergency events. Besides, the data shared by the local community in a disaster-struck area is collected and processed in the disaster command centers, enabling officials to analyze the situation and plan accordingly. IP cameras that can be connected to computers, mobile land teams, helicopters and planes can send very important images to command centers in real time. RFID technologies enables updating the systems with information on which treatment was performed on a certain disaster survivor and what kind of aid was provided to a certain person, and thus, prevents any duplications and abuses in the distribution of aids. This method is vital for those who are under risk in earthquake-prone areas. In short, though indirectly, the increased availability of communication technologies worldwide may help reducing the adverse consequences of disasters.

With the breakout of the COVID-19 pandemic in 2020, the scope of accessibility changed from physical accessibility to a space into accessibility to digital platforms. Relevant ministries should prepare, spread and make it easy to access public service ads, and persons with disabilities should be provided with proper access to the activities on disaster management and any relevant data. For disaster management, it is critical not only to provide access technologies and connection tools, but also to develop an infrastructure that can be combined with effective solutions towards facilitating communication and preventing any interruptions in access.

Increasing the frequency of disaster drills and raising awareness will help to further enhance social integration and cooperation before any disasters occur. At this point, special attention should 
be paid to disaster literacy. An environment of confidence based on public participation should be created, and the correct methods for communication should be utilized. Disaster awareness should be made a part of daily life by creating data maps. A plan for communication should be developed. Paying specific attention to privacy and security, geographical data can be embedded into widely used application such as the HES and e-Government to create a shared database and communication system. This can further evolve into a system that provides risk notifications before disasters and creates regional reports on needs.

The Disaster and Emergency Management Presidency (AFAD) at the Ministry of Interior makes use of tools including VR, GPS, drones, early warning systems, and AYDES disaster management system to manage risks, preparedness and measures before disasters. During disasters, remote sensing systems are used effectively to calculate the effects of the disaster and the provide supplies to camps. AFAD also ensures swift data transfers between ULAKBIM and AFAD TVDM (Earthquake Data Center System of Turkey) systems. This system is an outcome of the collaboration between the Turkish Atomic Energy Authority and the General Directorate of Geographic Information Systems at the Ministry of Environment and Urbanism, and it enables the transfer of knowledge between public authorities with various tools.

Warning sirens and integration-based systems are also used during disasters. Moreover, the Ministry installs siren systems across the country and deploys mobile communication vehicles in various locations to ensure uninterrupted communication during disasters. Mobile coordination trucks are used for further support. And thus, disasters can be managed more effectively. With help of the AFAD-RED program, scenarios are formulated to foresee the extent of the damage a disaster may cause. In the aftermath of a disaster, ULAKBIM - AFAD TVDM system may help to assess the damage. There are roughly 111 data monitoring centers in Turkey. The data obtained from these centers are collected in a single point in the data center to prevent any misinformation (URL 5, URL $6)$.

Given that, during a disaster, citizens may not be able to access the data sources that were prepared before the disaster, alternative solutions should be developed. Examples to such alternative solutions include RFID wristbands and radio systems. During disasters, up-to-date data should be used to ensure accurate and direct intervention, and access should be provided for each and every citizen.

\section{Conclusions}

This study scrutinized the current situation under four headings in terms of the intersection between accessibility in disasters and emergencies, and urban resilience, and emphasized the need for social harmony and an inclusive perspective. In Turkey, the legislative background in disaster risk management is outlined by numerous documents. With AFAD ensuring coordination, the roles and responsibilities of the Turkish Red Crescent and other stakeholders are clearly defined. Based on the evidence-based evaluations performed during the workshop as well as the comments provided by vulnerable groups, it is possible to draw the conclusion that social awareness is the step that does not function properly.

The awareness, competencies and knowledge of individuals should be increased in terms of both spatial construct and the social aspect, and the disaster preparedness aspect of the disaster management process should be handled with extra attention. Indeed, giving priority solely to the planning of the rescue and recovery activities during and after a disaster is not sufficient to achieve disaster resilience. Resilience in urban disasters refers to the ability of a community to adapt, to avoid dangers, and to reevaluate the consequences of a disaster to update the conditions in the event of natural and/or man-made disasters and hazards. As highlighted in its description, resilience means "adapting," "avoiding dangers," and "learning lessons from previous disasters and make future use of these lessons." When the expectations in these basic areas are met, it will be much easier to implement the policies in the specific topics mentioned under the disaster cycle. 


\section{References}

AFAD, 2011. Engelliler için Depremde ilk 72 saat. T.C. Başbakanlık Afet ve Acil Durum Yönetimi Başkanlığı. İstanbul iSMEP.

AFAD, 2014. Açıklamalı Afet Yönetimi Terimleri Sözlüğü, TC Başbakanlık Afet ve Acil Durum Yönetimi Başkanlığı, Kasım 2014

Page| 309 AFAD, 2015. HYOGO Çerçeve Eylem Planının Uygulamasına Yönelik Ulusal illerleme Raporu (2013-2015), Ankara.

AFAD, 2020 Afet Yönetimi Kapsamında 2019 Yılına Bakış ve Doğa Kaynaklı Olay İstatistikleri. TC İçişleri Bakanlığı, www.afad.gov.tr, Ankara, 2020

Balamir, M., 2001. Recent Changes in Turkish Disasters Policy: A Strategical Reorientation? In Mitigation and Financing of Seismic Risks: Turkish and International Perspectives (pp. 207-234), Springer Netherlands.

Bo Westerlund, 2007. A Workshop Method that Involves Users Talking, Doing and Making, Proceedings of international conference on human bowesterlund.se

Dinçer, ì., 2012. "Kültür Mirasının Korunmasında Risklere Hazırlık Kavramının Gelişimi, Mimarlık, s.364.ss:5659.

Doğan, H., 2021. 2020 Yılı Metorolojik Afetler Değerlendirmesi, Çevre Şehircilik ve İklim Değişikliği Bakanlığı Meteoroloji Genel Müdürlüğü, Ankara 2021

Erdem, U., Erdin, H.E., Özcan S.N., 2017. Afet ve Acil Durumlarda Erişilebilirlik, 4.Uluslararası Deprem Mühendisliği ve Sismoloji Konferansı, 11-13 Ekim 2017. Anadolu Üniversitesi, Eskişehir.

Erdin, H.E., Çelik, H.Z., Özcan, N.S. ve Aydın, M.B.S. (2016). Kentlerdeki afet yönetimine ilişkin kurumsal yapılanmanın kent planlama süreci içerisindeki etkisinin ve yerinin irdelenmesi. Uluslararası Doğal Afet ve Afet Yönetimi Sempozyumu (DAAYS'16), 2-4 Mart 2016, Karabük, Türkiye

Erdin, H.E., 2018. Doğal Afetler ve Kent Planlaması, Giriş: Doğal Afetlerin Etkileri, https://www.imo.org.tr/resimler/ekutuphane/pdf/18038_15_26.pdf

Ertugay K., ve Düzgün, S., 2006. "Integrating Physical Accessibility of Emergency Establishments into Earthquake Risk Assessment", Proceedings Geohazards, Engineering Conferences International. Ankara.

Güler Akın G. Tutal O., 2017. Accesibility and Usability of Historic Buildings, Uluslararası Katılımlı 6. Tarihi Yapıların Korunması ve Güçlendirilmesi Sempozyumu /2-3-4 Kasım 2017.

Hansen,H.S., 2009 Analysing the Role of Accessibility in Contemporary Urban Development, Springer link, ICCSA. Pp 385-396

Holling C.S., 1973 Resilience and Stability of Ecological Systems, Annual Review of Ecology and Systematics Vol. 4:1-23 (Volume publication date November https://doi.org/10.1146/annurev.es.04.110173.000245

Hoşgörmez, H., 2015 Afetlerde Bilişim ve Iletişim Teknolojilerinin Kullanımı, Acil Yardım ve Afet Yönetimi Lisans Tamamlama Programı, İstanbul Üniversitesi Açık ve Uzaktan Eğitim Fakültesi Ders Notu. İstanbul.

iтÜ Report 2021. Bozkurt Sel Afeti: Sebepler ve Tespitler https://haberler.itu.edu.tr/haberdetay/2021/08/20/bozkurt-sel-afeti-sebepler-ve-tespitler

Jha, A.K., Miner T.W, Stanton-Geddes, Z., 2013 Building Urban Resilience, Principles, Tools and Practice, The World Bank. Washington D.C.

Kadıoğlu, M., 2008 Modern, Bütünleşik Afet Yönetiminin Temel ilkeleri (Principles of Modern Integrated Disaster Management System), Kadıoğlu,M ve Özdamar,E (Editors) Afet Zararlarını Azaltmanın Temel İlkeleri , JICA Türkiye Ofisi Yayınları. No:2, s.1-34, Ankara.

Kalaycı,S., 2020 Engelli Bireylerin Kamusal Hizmetlere Erişebilmesinde Belediyelerin Yeri, Sosyal Politika Çalışmaları Dergisi, Cilt 1, Erişilebilirlik Özel Sayısı, s. 83-104.

Karadağ, H, Çağlayan Gümüş,D., Feyzioğlu G., Ayanoğlu,S., Sayan,T., Aydoğan, M.O., Çelik, A.D., Gözübek M., 2020. Accesibility Guide, Ministry of Family, Labour and Social Services.Ankara 2020.

Karadağ, H., 2020 Planlı Alanlar İmar Yönetmeliği, Kentleşme ve Erişilebilirlik, Sosyal Politika Çalışmaları Dergisi, Erişilebilirlik Özel sayısı, Cilt 1, Aralık 2020.ISSN: 2148-9424

Kentleşme Şurası/ Urbanization Council, 2009 Afetlere Hazırlık ve Kentsel Risk Yönetimi Komisyonu , Ankara

Onur, H., 2019. Kültür Varlıklarına Yönelik Afet Risklerinin Yönetimi (Zeynep Gül Ünal., Nevra Ertürk Editorler), İstanbul Tarihi Alanları Alan Başkanlığı, Maviay Ofset Etkilet Matbaa San. ve Tic. Ltd. Şti. ISBN 978-97517-4193-6.

Orhan, E., 2010. Afet Planlamasında Kaynak Kullanımının Siyasetinde Planlamanın Rolü, Planlama, 1 : 69-81, Ankara

Orhan, E., Keskinok, H.Ç., 2019 Spatial Planning Principles in Disaster Mitigation Targeting Individuals with Special Needs, Resilience Journal 3(1), 2019, (25-35) ISSN: 2602-4667 DOI: 10.32569/resilience.544903. 
Sarı V.I., Yener I.N., İnan Ö., 2018 Mekansal Planlama Sistemine Ilişkin Değerlendirme Raporu, TC Kalkınma Bakanlığı Bölgesel Gelişme ve Yapısal uyum Genel Müdürlüğü Kentsel ve Mekansal Gelişme Dairesi, Yayın no 2988.

Stough,L., McAdams Ducy, E., 2014. Disaster and Disabilities, Encyclopedia of Special Education (pp. 852-854). C. R. Reynolds, K. J. Vannest, E. Fletcher-Janzen (editors) New York: John Wiley \& Son.

Subaş Yurtçu, A.B.,2019. Özel Gereksinimli Bireylere ilişsin Temel Kavramlar, Özel Gereksinimli Bireyler için Afet ve Acil Durum Yönetimi, Onur Kurt (Editör), T.C. Anadolu Üniversitesi Yayını. No: 3832. E-ISBN 978975-06-3032-3.

The Turkish Red Crescent Disaster Report, 2020. Turkish Red Crescent Society, 2020, ISBN: 978605-5599-645.

Tutal O., 2020 Tarihi Çevre ve Erişilebilirlik / Historical Environment and Accesibility, Kentli Dergisi Mimari Erişilebilirlik Özel sayısı, Sağlıklı Kentler Birliği Yayını.

UN Department of Economic and Social Affairs 2018. Disability and Development Report, Realizing the Sustainable Development Goals by, for and with persons with disabilities. United Nations 2019.

UNISDR (United Nations International Strategy for Disaster Reduction). 2011. Global Assessment Report on Disaster Risk Reduction: Revealing Risk, Redefining Development. Geneva. http://www.unisdr.org/we/inform/publications/19846.

UNISDR 2014 Survey on Living with Disability and Disasters. UNISDR-The United Nation Office for Disaster Risk Reduction.

WHO-World Health Organization 2013. Guidance Note on Disability and Emegency Risk Manegement for Health, WHO Library Cataloguing-in-publication Data.

Zıvralı,i., Cabbar N., 2015. Kültür Varlıklarında Risk Yönetimi: Gelişimi, Güncel Durum ve Öneriler, 5. Tarihi Eserlerin Güçlendirilmesi ve Geleceğe Güvenle Devredilmesi Sempozyumu, Cilt 2, 1-3 Ekim 2015. Ankara.

URL-1 https://www.inclusivecitymaker.com/disabled-people-in-the-world-in-2021-facts-and-figures/

URL-2: https://irap.afad.gov.tr/en/42071/ABOUT-IRAP

URL 3- https://idealsosyalhizmet.com/sosyal-yardim-bilgi-sistemi-soybis-nedir/

URL 4-https://www.kizilay.org.tr/neler-yapiyoruz/afet-yonetimi

URL 5- https://www.afad.gov.tr/afet-yonetim-ve-karar-destek-sistemi-projesi-aydes21\#

URL 6- https://tdvms.afad.gov.tr/

\section{Resume}

Hatice Ayataç is a professor in the Department of Urban and Regional Planning at the Faculty of Architecture, ITU. She has researches, international and national publications, and conducts master's and doctoral theses on Urban Identity, Urban Public Space Design, Urban Memory and Memory, Urban Design Theory and History, Pedestrian Spaces, Barrier-Free Access, Children and Space. She was the congress secretary of the International Planning History (IPHS) congress in 2010. She has served as a member of the Scientific Board and Advisory Board international and National Scientific Meetings and continues. She is still a member of the executive board in the MARUF (2019-2021) organization held within the Marmara Municipalities Union and a member of the DOCOMOMO Turkey Working Group. She is also a Member of the Executive Board of the Turkish Red Crescent Istanbul Branch and a Member of the Board of Trustees of the Urban Transformation and Urbanization Foundation. She is the directorate of the Culture, Space and Memory Studies Program of Urban Research Institute. Within the scope of her professional experience, she worked as an executive and researcher in both national and international projects, and as a researcher in the Istanbul Environmental Plan Industry Sector Working Group. She is the owner of the idea and the implementation guide in the implementation of the Istanbul Airport Library Project, which is a first for our country, in the joint protocol of IGA, ITU, and the Ministry of Culture. 